УДК 551.521.37:725.1

\title{
РАЦІОНАЛЬНИЙ ВИБІР ЗОВНІШНЬОГО ОГОРОДЖЕННЯ СУЧАСНОГО БУДИНКУ
}

Канд. техн. наук Є.Є. Счастний, А.О. Воронець

\section{РАЦИОНАЛЬНЫЙ ВЫБОР НАРУЖНОГО ОГРАЖДЕНИЯ СОВРЕМЕННОГО ЗДАНИЯ}

Канд. техн. наук Е.Е. Счастный, А.А. Воронец

\section{RATIONAL CHOICE OF OUTWARD PROTECTION OF MODERN BUILDING}

Cand. of techn. sciences E.E. Schastny, A.O. Voronets

У статті розглянуті варіанти застосування декількох типів зовнішніх огороджень будівлі. Виконано порівняння конструкиій, розглянуті найбільш ефективні варіанти огороджень.

Ключові слова: опалювання, вартість огороджень, вартість будівництва.

В статье рассмотрены варианты применения нескольких типов наружных ограждений здания. Выполнено сравнение конструкиий, рассмотрены наиболее эффективные варианты ограждений. 
Ключевые слова: отопление, стоимость ограждений, стоимость строительства.

The article discussed applications of various types of exterior building protections. Four variants of constructions of protection are accepted - two traditional and two modern. To traditional options attributed fence made of foam concrete and brick with the use of insulation. Modern options of protections are based on use of blocks with application of expanded polystyrene and SIP panels. Taken into account values of thermal resistance to the heat transfer. It must be in the limits set by a normative document. Criterion for comparison was given the thermal resistance of the fence. According to this indicator, modern design better than traditional 1.5 ...3 times.

Keywords: heating, cost of protections, building cost.

При досягнутому рівні технологій будівництва важливою особливістю $\epsilon$ досягнення найменших тепловтрат. Існує великий вибір матеріалів 3 різними властивостями і характеристиками, безліч варіантів побудови будинку. Але для споживача $\epsilon$ важливим співвідношення ціна - якість. Особливо актуально це положення для індивідуальних забудовників, яких досить багато в країні. Тому актуально порівняти деякі найбільш характерні варіанти будівництва індивідуальних будинків 3 метою вибору раціональних матеріалів 3 позицій мінімальної ціни при максимальних теплоізоляційних властивостях.

Для порівняння прийняти варіанти

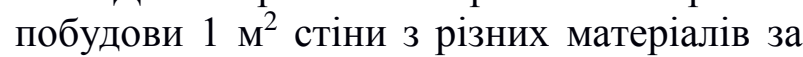
найбільш поширеними технологіями:

1 варіант: цегла, утеплювач, облицьовувальна цегла;

2 варіант: цегла облицьовувальна, пінобетон, штукатурка;

3 варіант: термодім (монолітна бетонна стіна, що обрамлена 3 внутрішнього і зовнішнього боків тепло- і звукоізоляційною оболонкою з пінополістиролу);

4 варіант: дім, що побудований за канадською технологією (стружкові плити, пінополістирол і поліуретановий клей).

Кліматичні умови будівництва прийняти для м. Києва.

Фактичне значення опору теплопередачі огородження $\mathrm{R}_{0}$ визначають за формулою, $\mathrm{M}^{2} \cdot \mathrm{K} / \mathrm{BT}$,

$$
\mathbf{R}_{0}=\mathbf{R}_{\mathrm{B}}+\sum_{\mathrm{i}=1}^{\Pi} \mathbf{R}_{\mathrm{i}}+\mathbf{R}_{3}
$$

де $\mathrm{R}_{\mathrm{B}}$ - термічний опір на внутрішній поверхні стіни, м $^{2} \cdot \mathrm{K} / \mathrm{B}$ :

$$
\mathrm{R}_{\mathrm{B}}=\frac{1}{\alpha_{\mathrm{B}}}
$$

де $\alpha_{\text {в }}-$ коефіцієнт тепловіддачі на внутрішній поверхні;

$\mathrm{R}_{3}$ - термічний опір на зовнішній поверхні стіни, $\mathrm{m}^{2} \cdot \mathrm{K} / \mathrm{B}$ :

$$
\mathrm{R}_{3}=\frac{1}{\alpha_{3}},
$$

де $\alpha_{3}-$ коефіцієнт тепловіддачі на зовнішній поверхні;

$\alpha_{\mathrm{B}}=8,7 \mathrm{BT} / \mathrm{M}^{2} \cdot \mathrm{K}, \alpha_{3}=23 \mathrm{BT} / \mathrm{M}^{2} \cdot \mathrm{K}[1$, дод.Е, c. 25].

$$
\sum_{\mathrm{i}=1}^{\Pi} \mathrm{R}_{\mathrm{i}}-\text { сума термічних опорів кожного }
$$
шару огородження, $\mathrm{M}^{2} \cdot \mathrm{K} / \mathrm{B}$ :

$$
\mathrm{R}_{\mathrm{i}}=\frac{\delta_{\amalg}}{\lambda_{\amalg}},
$$

де $\delta_{ш}, \lambda_{ш}$ - товщина, м і коефіцієнт тепо-провідності, Вт/м·К, шару огородження.

Для прикладу, фактичне значення опору теплопередачі огородження першого варіанта стіни, $\mathrm{M}^{2} \cdot \mathrm{K} / \mathrm{BT}$ :

$$
\mathrm{R}_{0}=\frac{1}{8,7}+0,437+2,17+0,21+\frac{1}{23}=2,98 .
$$


Фактичний термічний опір зовнішього огородження повинен відповідати нормативному значенню. Нормативний опір теплопередачі зовнішніх стін для першої температурної зони, в якій розташовано місто Київ, за ДБН В 2.6-31-2006 становить $\mathrm{R}_{\text {норм }}=2,8, \quad \mathrm{~m}^{2} \cdot \mathrm{K} / \mathrm{BT}$. Таким чином, для кожного 3 чотирьох варіантів конструкція зовнішнього огородження обрана згідно 3 будівельними нормами. Результати вибору зведені в таблицю. Крім того, в таблиці наведені значення поточних цін на зазначені будівельні матеріали, та приведеної вартості - відношення вартості $1^{2}$ огородження до його термічного опору.

Вибір зовнішніх огороджень будинку

\begin{tabular}{|c|c|c|c|c|c|c|c|}
\hline 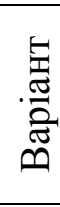 & Матеріал & $\begin{array}{c}\text { Товщи- } \\
\text { на, м }\end{array}$ & $\begin{array}{c}\text { Тепло- } \\
\text { провід- } \\
\text { ність, } \\
\text { Вт/(м·К) }\end{array}$ & $\begin{array}{c}\mathrm{R}, \\
\mathrm{M}^{2} \cdot \mathrm{K} / \mathrm{BT}\end{array}$ & $\begin{array}{c}\mathrm{R}_{0}, \\
\mathrm{M}^{2} \cdot \mathrm{K} / \mathrm{BT}\end{array}$ & $\begin{array}{l}\text { Bap- } \\
\text { тість, } \\
\text { грн/} / \mathrm{M}^{2}\end{array}$ & $\begin{array}{c}\text { Приведена } \\
\text { вартість, } \\
\left.\text { грн/( } \mathrm{M}^{2} \cdot \mathrm{K} / \mathrm{B}\right)\end{array}$ \\
\hline \multirow{3}{*}{1} & Цегла & 0,38 & 0,87 & 0,437 & \multirow{3}{*}{2,983} & \multirow{3}{*}{$\begin{array}{l}150- \\
200\end{array}$} & \multirow{3}{*}{$50,3-60,7$} \\
\hline & Утеплювач & 0,075 & 0,0345 & 2,174 & & & \\
\hline & $\begin{array}{l}\text { Облицьовувальна } \\
\text { цегла }\end{array}$ & 0,12 & 0,56 & 0,214 & & & \\
\hline \multirow{3}{*}{2} & $\begin{array}{l}\text { Облицьовувальна } \\
\text { цегла }\end{array}$ & 0,12 & 0,56 & 0,214 & \multirow{3}{*}{2,907} & \multirow{3}{*}{$\begin{array}{l}200- \\
300\end{array}$} & \multirow{3}{*}{$68,8-103,2$} \\
\hline & Пінобетон & 0,35 & 0,14 & 2,5 & & & \\
\hline & Штукатурка & 0,02 & 0,58 & 0,034 & & & \\
\hline 3 & «Термодім» & 0,25 & 0,036 & 6,944 & 7,103 & 301 & 42,4 \\
\hline 4 & $\begin{array}{l}\text { Дім за канадською } \\
\text { технологією }\end{array}$ & 0,12 & 0,035 & 3,429 & 3,587 & 1280 & 356,8 \\
\hline
\end{tabular}

Відповідно до таблиці, 3 технікоекономічних міркувань найбільш прийнятним варіантом $\epsilon$ використання традиційної технології і технології «Термодім». В основу останньої покладено зведення несучих стін 3 монолітного залізобетону за допомогою незнімної опалубки зі спеціального будівельного пінополістиролу у вигляді легких блоків. Блоки опалубки мають порожнини, які в процесі будівництва армуються i заповнюються бетоном. Спеціальна конструкція замків дозволяє швидко i точно з'єднувати блоки, що перешкоджає витіканню бетону. Таким чином, у ході однієї технологічної операції споруджується монолітна бетонна стіна, обрамлена 3 внутрішнього і зовнішнього боків тепло- і звукоізоляційною оболонкою з пінополістиролу.
Ефективні технології будівництва i високі теплоізоляційні властивості огороджень при використанні технології «Термодім» дозволяють рекомендувати іiі як для індивідуального будівництва, так і для будівництва громадських споруд. Економічний ефект може бути отриманий не тільки за рахунок меншої вартості будівництва, але i за рахунок значної економії на опалення споруди.

\section{Висновки:}

- одним 3 найбільш ефективних способів будівництва огороджень в умовах України $\epsilon$ використання технології «Термодім» із застосуванням спеціальних пінополістирольних блоків;

- при техніко-економічному обгрунтуванні конструкції зовнішнього огородження доцільно розглядати, крім технології «Термодім», також традиційну 
Підйомно-транспортні, дорожні, будівельні, меліоративні машини і обладнання

технологію будівництва і «канадську» технологію із застосуванням SIP-панелей;

- 3 урахуванням зміни вартості матеріалів для будівництва будівель і зростанням вартості енергоресурсів для їх опалення необхідно замислитися про зміну нормативних вимог до теплоізоляції будівель.

\section{Список використаних джерел}

1. ДБН В 2.6-31: 2006 Теплова ізоляція будівель. Міністерство будівництва, архітектури та житлово-комунального господарства України. - К.: Мінбуд України, 2006.

2. http://www.avisdom.com.ua/canadianhouse/technology/68-technology.

3. http://servusbud.com.ua/?page_id=1248/\#price.

4. http://kanadskiy-dom.com.ua/4buysip.html.

Рецензент д-р техн. наук, професор А.П. Фалендиш

Счастний Євген Свгенович, канд. техн. наук, доцент кафедри теплотехніки та теплових двигунів. Воронець Анна Олександрівна, слухач ІППК.

Schastny E.E., cand. of techn. sciences, Voronets A.O. 